\title{
Compliance with Standards and Immerging Issues of Household Sewage Disposal Systems in Gampaha Municipality Area in Western Sri Lanka
}

\author{
H. M. K. S. Bandara and M. M. M. Najim ${ }^{\#}$ \\ Faculty of Science, University of Kelaniya \\ Kelaniya, Sri Lanka \\ "Corresponding Author \\ Tel (Office): +94 11290 3413, 291 4479; Fax: +94 11291 4479; \\ Tel (Mobile): +94 77741 2089; Email:mnajim@kln.ac.lk; najimhn@yahoo.com
}

\begin{abstract}
Urban centers are highly significant with limited space together with the rising urban population. Most of the houses and buildings are attached with some kind of a sewage disposal facility as central sewage disposal systems are limited. Urbanization is expected to create many problems in terms of black water disposal due to limitation of land. A study was done in Gampaha municipality area, an urban center, where there is no central sewage treatment facility. The objectives of the study were to analyze the current situation of the black water disposal system in the study area and to identify the shortcomings of the black water disposal system comparing with the standards. The study was conducted within the urban center in five GN divisions. Random samples of 44 households were selected to represent all the five GN divisions. Selected households were interviewed to collect basic data needed and physical measurements were also taken where necessary. The data categories collected are household information, toilet type and size, desludging interval and distance to nearest well. The code of practice for the design and construction of septic tanks reports that $80 \%$ of urban communities use septic tanks for sewage disposal, but this study reveals that only $18 \%$ of the population uses septic tanks. Over $82 \%$ uses typical soakage pits that are constructed with loosely constructed brick walls and bare bottom open to soil for their sewage disposal. Over $68 \%$ of the households have their toilet pits within $15 \mathrm{~m}$ to the nearest well, which is below the recommended distance. Only $30 \%$ of the households comply with over $15 \mathrm{~m}$ to the nearest well that is recommended for septic tanks. The recommended distance for the soakage pits to the nearest well is 30m and only 9\% of the households meet this standard. The black water disposal pits are over sized in general, so that the desludging interval is more than 10 years. Recently constructed houses, due to limitation of space, have reduced the size of the pits reducing the size
\end{abstract}


of desludging interval. The construction and placement of septic tanks or soakage pits in the area have not complied with the standards.

KEYWORDS: Black water, Desludging, Septic tanks, Soakage pits, Wastewater

\section{Introduction}

Groundwater pollution with faecal contaminants have been a problem that mankind had been facing from great antiquity. Ancient Greek and Roman engineers had taken considerable care to separate used water or sewage from drinking water sources in their cities. Sri Lankans were one of the first nations to introduce the irrigation and irrigation management systems to the present world. The archaeological evidences also clearly demonstrate the advanced sanitation systems engineered by the ancient rulers. A well designed filtration system for a urinal found in the $5^{\text {th }}$ century "Abhayagiri" monastery in Sri Lanka shows how much of concern that had given to the problem of groundwater contamination with human waste. These are clear indications of the importance that our ancestors paid to the disposal of excreta (SACOSAN, 2003).

Urban areas are both consumers and producers of large amounts of water and wastewater. Providing good quality water and sanitation services to densely populated areas involves significant planning and infrastructure development (Corcoran et al., 2010). In most cities in developing Asia, sewerage and wastewater treatment is substandard. Many Asian cities suffer from poor sewerage networks and wastewater treatment systems; a large majority still depends on septic tanks and other on-site sanitation facilities. As a result, pollution loads in freshwater bodies and groundwater sources have increased substantially (ADB, 2010).

Unmanaged wastewater can be a source of pollution, a hazard for the health of human populations and the environment (Corcoran et al., 2010). Sri Lanka has gained somewhat a commendable water supply and sanitation coverage, both in urban and rural areas, compared to other countries in the region (SACOSAN, 2003). Sri Lanka has recorded substantial improvements in sanitary conditions in all districts within the past decade and has already achieved the Millennium Development Goal (MDG) target on access to improved sanitation (MDG Sri Lanka - Country Report, 2010).

Sri Lankan population can be classified mainly into three categories - urban (including peri-urban), rural and estate (mainly labour force employed in the tea and rubber estates). Sector wise population variation, according to the census of population and housing in 2001, shows 14.6 percent, 80.0 percent and 5.4 percent respectively, in urban, rural and estate areas. The situation in the Gampaha district 
is similar with the country's general figures, as 14.6 percent urban and 85.4 percent rural with negligible estate areas (DCS, 2001).

There are several commonly used onsite sewage disposal and treatment systems in the world; most common and well known method is the septic tank with a soakage pit system (Werellagama et al., 2003). A septic tank is defined as a single or multiple-chambered tank in which wastewater is retained sufficiently long to permit separation of solid particles and partial digestion of accumulated solids (SLSI, 2003). The main function of a septic tank is to separate, retain and partially digest settleable and floatable solids in wastewater. The working capacity of a septic tank shall be sufficient for all these functions to occur.

Septic tanks are widely used in Sri Lanka for the disposal of domestic wastewater. At present, at least 80 percent of the urban and suburban population of Sri Lanka uses septic tanks (SLSI, 2003). However, unless a septic tank and associated effluent disposal system are properly designed and implemented, failures occur with consequent aesthetic nuisance, public health hazard and environmental pollution (SLSI, 2003).

As the pollution potential of septic systems become more widely recognized and as pollution by septic systems become more widespread in the urban context, pressure to develop and implement rational and effective standards for septic tanks will increase. At present, there is no uniform approach among regulatory agencies to setting standards. Past experience suggests that regulation of septic tank density is an effective means of minimizing pollution potential and that regulation of penetration depth of wells into groundwater and separation distance between wells and drain fields are insufficient preventive measures when used alone (Perkins, 1984). The most commonly applicable options for the disposal of septic tank effluent in Sri Lanka are soakage pit or a seepage bed.

In the past, the commonest single cause of failure of septic tank systems in Sri Lanka has been the indiscriminate use of soakage pits for the disposal of septic tank effluents into the ground. This has invariably been done without due consideration to local soil conditions, groundwater table and urban congestion leading to widespread failures. Often, this has been due to the lack of awareness of implementers and regulators of appropriate alternative cost-effective means of effluent disposal.

Septic tank effluent often contains many viral, bacterial and protozoan pathogens. According to the reviews of Rose and Gerba (1991), viruses and protozoa generally have much lower infectious doses than bacteria and, for some viruses, as little as one organism could cause infection. Protozoans are expected to have lower input concentrations and generally larger particle size than bacteria and viruses (and 
hence are more likely to be filtered out), thus they are unlikely to control the setback distances (Pang et al., 2003).

The use of groundwater contaminated by human effluent could cause many waterborne diseases (Pang et al., 2003). According to World Health Organization (WHO) estimates, nearly 3.3 million people, including 2.5 million children die of diarrheal diseases annually. Similarly, 1.5 billion people suffer at any given time from parasitic worm infections stemming from human excreta and solid wastes in the environment. The main source of this is the water contaminated with human faeces, for example, from sewage, septic tanks and latrines, is of particular concern (Anonymous, 1998).

\section{Standard Levels and Regulations}

To protect drinking water wells and recreational surface water bodies against microbial contamination, government authorities have often used arbitrarily determined setback distances from septic tank systems (Pang et al., 2003). Removal of microorganisms of the septic tank effluents is by die-off, filtration and sedimentation. Naturally die-off is common for all microorganisms and filtration and sedimentation which are important processes, particularly for bacteria. Sorption and dilution are responsible for more than $50 \%$ of the natural attenuation process of groundwater contaminants (Todd, 1980). Dilution mainly occurs due to recharge of groundwater by natural precipitation or infiltration from surface water bodies.

Number of standards has been developed in different parts of the world to minimize the contamination of drinking wells by faecal contaminants. The most basic and important one among these is the minimum distance / setback distances between the source of pollution and the drinking well. Setback distances are site-specific. For adequate determination of setback distances, information on attenuation and transport of pathogens or microbial indicators in groundwater systems is needed (Pang et al., 2003).

Presently there is a standard distance of 50 feet $(18 \mathrm{~m})$ observed under the local government by laws which had been in existence for nearly one hundred and fifty years (stipulated under the national standard SLS 745). Septic tanks should be desludged at the appropriate intervals according to the design and use of the tank. Typically, this is when the tank is between one third and half full of sludge (SLSI, 2003). Septic tanks shall be located in an open area wherever possible. However they may be located under car parks, driveways, terraces etc., in order to save space, provided due consideration is given to the structural integrity of the tank and adjacent features. Soakage pits shall be located in an open area and at least $18 \mathrm{~m}$ away from the nearest well or other drinking water source. 
These arbitrary distances may under or overprotect water resources. Setback distances are site-specific. For adequate determination of setback distances, information on attenuation and transport of pathogens or microbial indicators in groundwater systems is needed. Pang et al. (2003) has shown that it is possible to determine the setback distance through a field sampling program and through model prediction.

Septic tanks shall be water-tight, with sufficient structural strength and integrity to withstand external soil pressures, internal and external water pressures and any likely imposed loading. Septic tanks situated under driveways and parking areas shall be designed to carry the appropriate vehicle loads. Accurate site information and assessment is vital to avoid failure of septic tank systems.

\section{Current Situation}

MDG Sri Lanka - Country Report (2010) illustrate that Sri Lanka has achieved the required target level of the percentage of the population with access to facilities that hygienically separate human excreta from human, animal and insect contact. Facilities such as sewers or septic tanks, pour-flush latrines and simple pit or ventilated improved pit latrines are assumed to be adequate, provided that they are not public, according to the World Health Organization (WHO) and United Nations Children's Fund (UNICEF). WHO, UNICEF, WSSCC (2000), showed that the population coverage by sanitation in Sri Lanka is $83 \%$. This is a high figure, with respect to other South - Asian regional countries.

Septic tanks are a prime breeding location for mosquitoes. Due care shall be taken to ensure that tanks are properly sealed. Structural cracks and vent pipes needed to inspected regularly and covered with appropriate covering. Increasing trend of urbanization and waterborne diseases in the Gampaha municipality limits had led to evaluate the current sewage disposal systems of the area with the prevailing standards. This field study focused on selected Grama Niladhari (GN) divisions of the Gampaha municipality area with the objectives to identify the available black water disposal systems of the Gampaha municipality area and to evaluate the shortcomings of the current black water disposal systems in Gampaha municipality area comparing them with the national and international standards.

\section{Methodology}

\section{Study Sites}

Study sites selected for this research included five Grama Niladhari (GN) divisions from the $33 \mathrm{GN}$ divisions within the Gampaha municipality area (Gampaha Municipal Council, 2008). Gampaha municipality area consists with a mixture of 
urban, peri-urban and rural features. The core area of the study, which is the Gampaha town area, can be considered to have a complete urban profile. According to the geographical conditions, Gampaha district belongs to coastal plain and to the low-country which is demarcated as the land below $300 \mathrm{~m}$ in elevation (Punyawardena, 2008).

Gampaha municipality area is located in the low country wet zone with an annual rainfall over $1700 \mathrm{~mm}$ distributed mainly from September to November during the second inter-monsoon and March to May during the first inter-monsoon (Punyawardena, 2008). The selected area belongs to the wet zone, low country $\left(\mathrm{WL}_{3}\right)$ agro-ecological region. Main soil types of the area are red yellow podzolic soils with soft and hard laterite, low humic glay and regosol soils.

Five GN divisions from the core area of Gampaha municipality namely Bandiyamulla North (224), Medagama 1 (223), Medagama 2 (223 A), Medagama 3 (223 B) and Medagama 4 (223 C) were selected for this study. Random samples of 44 households were selected to represent all the five GN divisions. Selected households were interviewed to collect basic data needed and physical measurements were also taken when necessary.

A questionnaire with two separate sections was developed to collect the household data needed for the study. Section one of the questionnaire captured the personal profile of the households and was designed to gain information on the household's social, economic and demographic characteristics. Section two contains the information on the house, water usages, toilet types, the sewage disposals systems and surrounding water sources.

As primary data, number of people in the household, age classes, type of house, land area $\left(\mathrm{m}^{2}\right)$, main water source, number / type of toilets used, type of the sewage disposal system, size of the sewage disposal system, desludging interval and distance to the nearest well were collected from the households selected. The field study was carried out from February 2010 to May 2010. The interview was conducted in Sinhala, the main language spoken by the residencies of the study area.

\section{Results and Discussion}

An inspection of sanitation type by relative standard of living confirms that betteroff households are more likely to make use of an improved latrine or a flush toilet in the study area. Sewerage coverage in Colombo city is 14\% (ADB, 2010), where most of the other cities has no central sewage disposal systems. The coverage of the central sewage disposal system is much smaller compared with the other main cities in the region. Gampaha does not have a main sewer system within the municipality 
area. This is crucial in an urban centre, where the space is minimum for individual household level sewage disposal systems. Most of the urban cities have opted for central sewer systems due to lack of available space.

Table 1 shows the sewage disposal systems of the randomly selected sample of the study area. Septic tank systems are less common (18.2\%) than that of the soakage pits $(81.8 \%)$ in the study area of the Gampaha municipality area. Even the use of septic tank systems are recommended, many of the households in the study area do not utilize a proper system as recommended. Soakage pit, a secondary sewage treatment unit, is defined as a pit from which septic tank effluent is allowed to seep into the surrounding soil (SLSI, 2003) but, irrespective to the definition, majority of the households (about 82\%) uses the soakage pits as their main and primary sewage disposal system.

Results of the current study contradict with the statement given by the SLSI (2003) "at least 80 percent of the urban and suburban population of Sri Lanka uses septic tanks". This may be due to false identification or interpretation of the two sewage disposal systems, septic tanks and the soakage pits.

Table 1: Type of the sewage disposal system of the household and its percentage to the total studied households

\begin{tabular}{cc}
\hline $\begin{array}{c}\text { Type of the } \\
\text { Sewage Disposal System }\end{array}$ & $\begin{array}{c}\text { Percentage to the } \\
\text { Total Households (\%) }\end{array}$ \\
\hline Septic tanks & 18.2 \\
Soakage pits & 81.8 \\
Main sewer & 0.0 \\
\hline
\end{tabular}

Discharge of the septic tank effluent after the primary treatment should be through a free-drained soakage bed or any other similar system of secondary treatment facility. The majority of the existing soakage pits are draining the effluents directly to the soil with a great risk of contamination of faecal matter with the surroundings. As these soakage pits are used as primary sewage treatment unit, the effluents soaked into the soil could be untreated sewage leading to high groundwater contamination risk. The water table level was very shallow in the area therefore the faecal contamination with the groundwater is more likely to occur.

The results show that the volumes of the cisterns available within the selected households are much higher than that of the designed working capacity of a septic tank (Table 2). Over sizing of the system may lead to increased desluding interval, generally over 10 years. Increase of this period may contribute more on contaminating the groundwater, soil and surroundings if the system is not 
constructed adhering to the standards. This may be due to the lack of technical knowledge of the draftsmen and masons in the construction process. If the households were connected with a central sewage disposal system, they would have saved the space taken for the septic tanks. It was observed that the more recent constructions of the study area have considerably small septic tank systems which will eventually reduce the desluding interval.

Table 2: Average design working capacities with respect to desludging interval

\begin{tabular}{cc}
\hline $\begin{array}{c}\text { Desludging Interval } \\
\text { (Years) }\end{array}$ & $\begin{array}{c}\text { Average Design } \\
\left.\text { Working Capacity } \mathbf{( m}^{\mathbf{3}}\right)\end{array}$ \\
\hline 05 & 1.18 \\
10 & 1.83 \\
\hline
\end{tabular}

Table 3: Minimum distance to the nearest well from the septic tank/ soakage pit of the household and its percentage to the total studied households

\begin{tabular}{cc}
\hline $\begin{array}{c}\text { Minimum Distance to } \\
\text { Nearest Well }\end{array}$ & $\begin{array}{c}\text { Percentage to the } \\
\text { Total Households }(\%)\end{array}$ \\
$<15 \mathrm{~m}$ & 68.2 \\
$\geq 15 \mathrm{~m}$ & 31.8 \\
$\geq 18 \mathrm{~m}$ & 25.0 \\
$\geq 30 \mathrm{~m}$ & 9.1 \\
\hline
\end{tabular}

The results of this field study revealed that the majority of the households in the study area have their sewage disposal system close to the nearest water source / water body (Table 3). A percentage of over $68 \%$ of the selected households have only a minimum distance between the onsite sewage disposal system and the water source that is less than $15 \mathrm{~m}$, which is obviously below the recommended distance (Table 4).

Table 4: Different setback distances for soakage pits recommended by different sources (Werellagama and Hettiarachchi, 2004)

\begin{tabular}{cc}
\hline Source & Recommended Distance \\
\hline PHI manual, Sri Lanka & $15 \mathrm{~m} / 50$ feet \\
SLS 745 & $18 \mathrm{~m} / 59$ feet \\
USA (Federal regulations) & $30 \mathrm{~m} / 98 \mathrm{feet}$ \\
WHO (wet areas with rapidly moving GW) & $30 \mathrm{~m} / 98 \mathrm{feet}$ \\
\hline
\end{tabular}


The households which comply with the minimum standard distance are over $31.8 \%$ of the total selected households. The minimum distance of $15 \mathrm{~m}$ is according to the PHI manual of Sri Lanka and the SLSI standard for this is $18 \mathrm{~m}$ which is slightly higher compared to the PHI manual. Even the percentage of the household which complies with the SLSI standard is only $25 \%$. The highest minimum distance recommended by a standard is $30 \mathrm{~m}$ which is imposed by the WHO for those areas in the wet zone with rapid movement of groundwater. Although the situation in the study area is not so related, the percentage households those are within this level of the standard are just at $9 \%$.

Setback distances for soakage pits seem to be greatly varying under different standards maintained in other parts of the world. On the other hand it is quite obvious that such a standard cannot be a geographical constant in a country like Sri Lanka where there are considerable geological, topographical, climatic and demographical variations among different parts. These arbitrary distances may under or overprotect water resources. Setback distances are site-specific. Pang et al., (2003) stated that for adequate determination of setback distances, information on attenuation and transport of pathogens or microbial indicators in groundwater systems is needed.

In a country like Sri Lanka especially in the wet zone there is a high demand for land and people are increasingly settling in very small land plots. Then a setback distance which is a geographical constant would not be an economically sound policy. In the other hand the set back distance of 18m (59ft) given in SLS 745 is much smaller than the value of $30.5 \mathrm{~m}$ (100ft) observed in most of the Sates of the United States of America (Table 4). In areas where there is highly sloping terrains which receive a considerable mean annual rainfall, this setback distance of $18 \mathrm{~m}$ might not be safe.

Therefore, it is recommended to calculate the setback distance according to a standard method to suit the field conditions. Werellagama et al. (2003) have stated that the present setback distance of $18 \mathrm{~m}$ stipulated by the national standard is calculated on the basis that a water particle would take at least two days to travel. Therefore, it is good to stick with the given standards for the minimum setback distances.

With regards to the municipal sewage, water quality deterioration occurs due to the improper designing, placement and construction failures of the septic tanks, soakage pits and any other form of sewage disposal system. Pang et al. (2003) has shown that septic tank effluent may enter the groundwater with bacterial concentrations similar to raw effluent concentrations, especially for those sites where the water table rises to flood the disposal trench/bed of a septic tank system. Gampaha 
municipality area is prone to annual floods during the rainy season due to its lowland nature and the nearby main stream "Dandugam Oya".

This geographical nature has made the study area more prone to faecal contamination with the water sources both surface and underground. Having a majority of the households below the recommended level of the minimum distance between the sewage disposal system and the water source, the authorities should be keener on imposing laws and regulating them.

Cities are not homogenous and are at different stages of economic, social, legal and institutional development. In addition, at least in terms of water supply, climate conditions, geography and soil type may vary from one city to another; even within a single medium-to-large country these features are seldom similar. Under these conditions, there is no question that one universal standard does not fit all.

Safe drinking water and basic sanitation are indispensable to primary health care and human development. They are a precondition for success in the fight against poverty, hunger and child deaths and in achieving gender equality (UNICEF, 2006). Sri Lanka has recorded substantial improvements in sanitary conditions in all districts, but the construction and the placement of most of the existing sewage disposal systems with the governing standards are a question in the study area of Gampha municipality whereas, the situation may be more or less similar in the other urban centers of the country.

As part of the Millennium Development Goals for sanitation, many countries are attempting to address the challenges of water supply and improved sanitation facilities for all without necessarily paying attention to the disposal of the increasing volumes of wastewater that are being discharged, in many instances, into the natural drainage systems and streams of the cities (Raschid-Sally and Jayakody, 2008).

It is estimated that 15 percent of the Sri Lankan population live in urban areas (areas under Municipal councils and Urban councils) and about 5 percent of the urban dwellers live in slums or shanties (MDG Sri Lanka - Country Report, 2010). Though there is dearth of reliable and accurate information on slum dwellers of Sri Lanka, the most of the urban residents are poorly housed due to the lack of space or / and poverty associated with them. This has been the major course for the nonconformity with the standards of the sewage disposal systems in the urban centers which is the same situation in the study area as well.

Densification of urban areas reduces the possibility for on-site disposal via septic tanks further. Centralized treatment systems in developing countries like Sri Lanka are not always affordable anyway, and when they are in place, they have always been vulnerable to the vagaries of skills, and institutional and financial capacities 
found in these countries (Raschid-Sally and Jayakody, 2008). In countries like Singapore, wastewater management is an integral part of the country's water policy as it completes the water cycle (ADB, 2010). Sri Lanka also should be integrating polices on sewage disposal and wastewater management at national level.

\section{Conclusion}

Gampaha, a rapidly developing urban center will continue to increase their demand for water and wastewater services, same as the other developing cities in the country. The majority of the households in the selected five GN divisions in the Gampaha municipality area are not complying with the national and international standards. If the city, further do not keep pace with development adhering to the standers imposed, it will face a number of difficult issues, such as deteriorating environmental conditions due to pollution and increased extraction of groundwater.

\section{References}

ADB (2010). Every Drop Counts: Learning from Good Practices in Eight Asian Cities, Asian Development Bank, Mandaluyong City, Philippines.

Anonymous (1998). Chapter 1, Introduction to Water Supply and Sanitation Projects, Guidance Manual on Water Supply and Sanitation Programmes, K. Clarke, Eds, Water, Engineering and Development Centre (WEDC) and Department for International Development (DFID), London, United Kingdom.

Corcoran, E., C. Nellemann, E. Baker, R. Bos, D. Osborn, D. and H. Savelli (Eds) (2010). Sick Water? The Central Role of Wastewater Management in Sustainable Development. A Rapid Response Assessment. United Nations Environment Programme, UNHABITAT, GRID-Arendal.

DCS (2001). Brief Analysis of Population and Housing Characteristics, Population and Housing Censuses in Sri Lanka 2001. Department of Census and Statistics, P. O. Box 563, Colombo, Sri Lanka.

Gampaha Municipal Council (2008). Annual Report, Gampaha Municipal Council, Gampaha, Sri Lanka.

MDG Sri Lanka - Country Report - 2010. Millennium Development Goals Sri Lanka: Country Report 2008/2009 Colombo: Institute of Policy Studies of Sri Lanka, 2010.

Pang, L., M. Close, M. Goltz, L. Sinton, H. Davies, C. Hall and G. Stanton (2003). "Estimation of Septic Tank Setback Distances Based on Transport of E. Coli and FRNA Phages", Environment International, 29: 907-921. 
Perkins, R. J. (1984). "Septic Tanks, Lot Size and Pollution of Water Table Aquifers", Journal of Environmental Health, 46(6): 298-304.

Punyawardena, B. V. R. (2008). Rainfall and Agro-ecological Regions of Sri Lanka. Natural Resource Management Centre, Department of Agriculture, Peradeniya, Sri Lanka, 1317, 39, 100-101 pp.

Raschid-Sally, L. and P. Jayakody (2008). Drivers and Characteristics of Wastewater Agriculture in Developing Countries: Results from a Global Assessment. Colombo, Sri Lanka: International Water Management Institute. 35p. (IWMI Research Report 127).

Rose, J. B. and C. P. Gerba (1991). Use of Risk Assessment for Development of Microbial Standards. Water Sci Technol, 24(2): 29- 34.

SACOSAN (2003). Chapter 4: Country Paper on Sanitation. (M. Feroze Ahmed, Sk. Abu Jafar Shamsuddin, Ryan Knox, Ed) In: Proceedings of South Asian Conference on Sanitation (SACOSAN) - 2003, Dhaka, Bangladesh, 21-23 October, 2003.

SLSI (2003). Draft Sri Lanka Standard - Code of Practice for the Design and Construction of Septic Tanks and Associated Effluent Disposal Systems. Sri Lanka Standards Institution, No. 17, Victoria Place, Off Elvitigala Mawatha, Colombo 08. Sri Lanka.

Todd, D. K. (1980). Ground Water Hydrology, $2^{\text {nd }}$ Ed., John Wiley and Sons, New York.

UNICEF (2006). UNICEF Annual Report 2005, The United Nations Children's Fund (UNICEF), New York, USA.

Werellagama, D. R. I. B., G. Herath, M., Hettiarachchi and S. Basnayake (2003). Report on Recommendations and Suggestions on the Standard Distance between a Potential Faecal Pollution Source and a Drinking Well in Sri Lanka, Environmental Engineering Laboratory, Faculty of Engineering, University of Peradeniya, Sri Lanka.

Warellagama, D. R. I. B. and M. Hettiarachchi (2004). Safe Distance between a Dinking Well and a Fecal Pollution Source for Sri Lanka, Annual Research Symposium, NWS \& DB, Sri Lanka.

WHO, UNICEF, WSSCC (2000). Global Water Supply and Sanitation Assessment 2000 Report, World Health Organization and United Nations Children's Fund. 